\title{
Synopsis of the helminth communities of the lacertid lizards from the Balearic and Canary Islands
}

\author{
Vicente Roca $^{1,2,}$, Fátima Jorge $^{2}$, Miguel Ángel Carretero ${ }^{2}$ \\ ${ }^{1}$ Departament de Zoologia, Facultat de Ciències Biològiques, Universitat de València, Spain. \\ ${ }^{2}$ CIBIO-UP, Centro de Investigação em Biodiversidade e Recursos Genéticos, Vairão, Portugal. \\ * Correspondence: Departament de Zoologia, Facultat de Ciències Biològiques, Universitat de València. Dr. Moliner 50, 46100 Burjassot, \\ Spain. Phone: +34 963544606, Fax: +34 963543049, E-mail: Vicente.roca@uv.es
}

Received: 16 October 2012; received in revised form: 15 November 2012; accepted: 18 November 2012.

Helminth communities of reptiles have usually been considered as depauperate and isolationist, with low abundance and species richness when compared to other vertebrates. Nevertheless there are some insular reptile populations in which this general rule is not fulfilled. In this study, we compare helminth faunas from two groups of lizards living in two different archipelagos and having different feeding habits. Lacertid lizards from Canary Islands, belonging to the endemic genus Gallotia, showed by contrast with other lacertids, a tendency to high consumption of plant matter and to rich and diverse helminth communities. Differences were found even between the lizards living in different islands, being the "giant lizard" G. stehlini the most herbivorous and $G$. atlantica the most carnivorous. Podarcis spp. from Balearic Islands showed lower tendency to herbivory which was not mirrored in their helminth communities. The composition and structure of helminth communities of lacertid lizards from both archipelagos are related to the conditions of insularity and the phylogeny of the hosts.

Key words: Balearic Islands; Canary Islands; helminthes; lizards.

Sinopsis de las comunidades helmínticas de los lagartos de las Islas Baleares y Canarias. Las comunidades helmínticas de los reptiles han sido consideradas generalmente como depauperadas y aislacionistas, con escasa riqueza y abundancia de especies comparadas con otros vertebrados. Sin embargo esta norma general no se cumple en algunas poblaciones de reptiles insulares. En el presente estudio se comparan las helmintofaunas de dos grupos de lagartos que habitan dos archipiélagos diferentes, y que exhiben distintas estrategias de alimentación. Los lagartos de las Islas Canarias, pertenecientes al género Gallotia, mostraron, en contraste con otros lacértidos, una tendencia hacia un alto consumo de materia vegetal y al establecimiento de ricas y diversas comunidades helmínticas. Se encontraron diferencias entre lagartos que habitan diferentes islas, siendo G. stehlini el más herbívoro y G. atlantica el más carnívoro. Las lagartijas Podarcis spp. de las Islas Baleares mostraron menor tendencia hacia el herbivorismo, tendencia que no se ve reflejada en sus comunidades helmínticas. La composición y estructura de las comunidades helmínticas de los lagartos de ambos archipiélagos se conforman de acuerdo con las condiciones impuestas por la insularidad y por la filogenia de los hospedadores.

Key words: Islas Baleares; Islas Canarias; helmintos; lagartos.

Studies on the community ecology of parasites of European reptiles, and particularly lacertids, have increased in the last years. In this context, islands have received less attention, although they are very interesting areas since they show peculiar conditions that may influence the characteristics of the populations of both parasites and hosts. From the point of view of the lizard hosts, pressure by terrestrial predator is lower for insular lizards than for 
their continental relatives (Novosolov et al., in press). This results in: (i) high lizard densities increasing intraspecific competition (including cannibalism on juveniles) and favouring conservative reproductive strategies (CARRETERO, 2006); (ii) lower, unpredictable prey availability promoting alternative trophic strategies, including kleptoparasitism and herbivory (PÉrez-Mellado \& Corti, 1993; VAN DAmMe, 1999; Carretero, 2004); (iii) a trend to larger body size and more accentuated sexual dimorphism (MEIRI, 2007; NovOSOLOV et al., in press). Last but not least, the abovementioned processes display substantial phylogenetic signal and depend on the time of evolution in insular conditions (CARRETERO, 2006). All these aspects are potentially important for the formation of parasite communities, namely in terms of promoting reproductive isolation between islands, increasing probability of infestation by conspecifics while decreasing that from heterospecifics, creating new infestation pathways and providing different usually more complex host environments. The island syndrome has also been reported in nematode parasites, with loss of genetic diversity and a niche enlargement (NiebERDING et al., 2006). The founder host may reach islands with only a subset of their parasite fauna, resulting in a decrease in species richness when compared with the continental relatives. This loss of richness has been detected also in helminth species of small mammals of Mediterranean islands, which was correlated with the area of the island and distance from mainland and decrease of host specificity (MAS-COMA et al., 2000; GOÜY DE BELLOCQ et al., 2002).

In the two last decades our laboratory has carried out studies about helminth parasites from Mediterranean and Atlantic islands (i.e. RocA et al., 1987; RocA, 1993, 1999; ROCA \& HORNERO, 1994; MARTIN \& Roca, 2004a,b; CARRETERO et al., 2006; RoCA et al., 2006, 2009; JORGE et al., 2012). We focused on the archipelagos of the Balearic and Canary Islands both administratively belonging to Spain but located at different geographic areas, namely in the Mediterranean Sea and the Atlantic Ocean, respectively (Fig. 1a), which have undergone quite divergent paleogeographic histories (see below). Lacertid lizards inhabiting each archipelago are also different. The Balearic Islands are occupied by two endemic species of the genus Podarcis Wagler, 1830, widely ranging the Mediterranean Basin, belonging to the Palearctic clade of Lacertini (ARNOLD et al., 2007). By contrast, lacertids living in the Canary Islands are represented by species of the endemic genus Gallotia Boulenger, 1916, a lineage phylogenetically distant from most other lacertids including Lacerta or Podarcis (HARRIs et al., 1998; ARNOLD et al., 2007; PAVLICEV \& MAYER, 2009). Abovementioned characteristics of the history of both archipelagos and their lizards, and also reproductive isolation conducting to new host species and subspecies (MACA-MeYer et al., 2003; Cox et al., 2010), and so new possibilities for new parasite species (and subspecies), could give rise to the current parasite faunas of these hosts.

Canary Islands are volcanic. They erupted from the sea and are considered as "oceanic islands", that is, never being connected to the African continent. They are located off the north west coast of Africa (Fig. 1a), at $27^{\circ} 37^{\prime}-29^{\circ} 24^{\prime} \mathrm{N}, 13^{\circ} 37^{\prime}-8^{\circ} 10^{\prime} \mathrm{W}$, and 

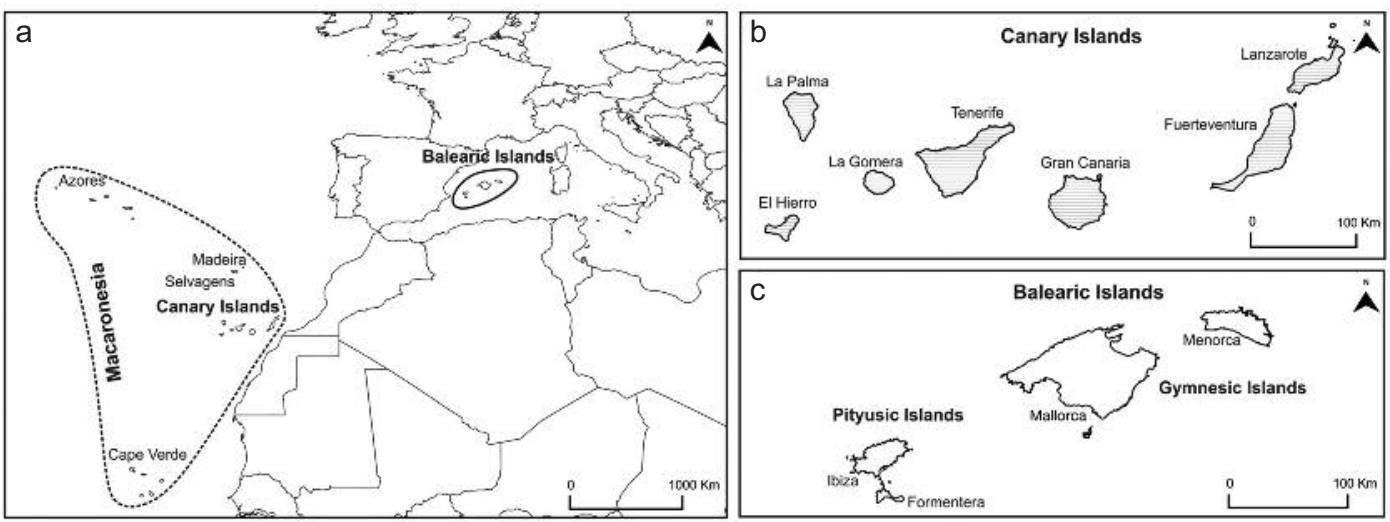

Figure 1: Localization of the Balearic and Canary Islands. (a) General localization. (b) Canary Islands. (c) Balearic Islands.

comprises seven main islands and a number of peripheral islets (Fig. 1b) having a total surface of $7493.65 \mathrm{~km}^{2}$ and being their maximum elevation $3718 \mathrm{~m}$ above sea level (Teide Volcano in Tenerife island). They form the biogeographical region of Macaronesia together with Cape Verde, Madeira, Azores and Selvagens archipelagos (Fig. 1a). Balearic Islands are "continental islands" that were part of the continent before reaching to be islands. In fact they constituted a part of the Iberian Peninsula known as "Balearic headland". Successive fractures and isolations gave rise to the actual conformation of this archipelago (Cavazza \& Wezel, 2003). They are located east of the Iberian Peninsula (Fig. 1a), at

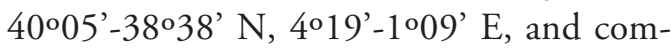
prises five main islands and a number of peripheral islets (Fig. 1c) having a total surface of $5014 \mathrm{~km}^{2}$, ranging in elevation from the sea level to $1445 \mathrm{~m}$ above sea level.

In this study we synthesize the results obtained in the parasitological analysis of lizards of both archipelagos and we compare their parasite faunas in the light of the biotic and abiotic features of the hosts.

\section{MATERIALS AND METHODS}

Gallotia lizards from the Canary Islands were captured in the main islands (Lanzarote, Fuerteventura, Gran Canaria, Tenerife, La Palma, La Gomera and El Hierro) during several periods between 1994 and 1997. From 1987 to 1989, Podarcis lilfordi were captured in some peripheral islets surrounding Mallorca and Menorca islands (Gymnesic islands) and Podarcis pityusensis were captured in Pityusic islands (Ibiza and Formentera) and some peripheral islets. The number of specimens of sampled lizards is detailed in Table 1. All lizards were captured by hand and were killed with an overdose of chloroform. The body cavity, digestive tract, heart, lungs, and liver were removed, opened, and placed in Ringer's solution for examination. Helminthes were removed, washed in distilled water, fixed, and mounted according to standards techniques. Parasites were identified, when possible, to species, and the number and location of individuals of each parasite species were recorded.

The use of descriptive ecological terms follows BusH et al. (1997). Brillouin's index 
Table 1: Host species and number of individuals analyzed in each archipelago.

\begin{tabular}{llc}
\hline \hline Island & Lizard Species & Number of inspected hosts \\
\hline Balearic Islands & & \\
Gymnesian (islets surrounding Mallorca and Menorca)* & Podarcis lilfordi & 386 \\
Pityusic (islets surrounding Ibiza and Formentera)* & Podarcis pityusensis & 564 \\
Canary Islands & Gallotia atlantica & 70 \\
Lanzarote & Gallotia atlantica & 42 \\
Fuerteventura & Gallotia stehlini & 33 \\
Gran Canaria & Gallotia galloti & 27 \\
Tenerife & Gallotia galloti & 27 \\
La Palma & Gallotia caesaris & 21 \\
La Gomera & Gallotia caesaris & 318 \\
El Hierro & & \\
\hline
\end{tabular}

*For details see Roca \& Hornero (1994).

of diversity was used for calculating diversity according to MAGURRAN (2004).

\section{RESULTS}

Seventeen helminth species (two Trematoda, four Cestoda, 10 Nematoda and one Acanthocephala) were found in the Balearic hosts. Twenty four (one Trematoda, five Cestoda, 17 Nematoda and one Acanthocephala) were recorded in Canarian hosts. Table 2 shows the presence/absence of helminth species recorded in the hosts.

Global prevalence of infection and overall diversity parameters for each host are given in Fig. 2 and Table 3, respectively.

In all the hosts, Pharyngodonidae nematodes (species of the genera Skrjabinodon, Spauligodon, Parapharyngodon, Thelandros, Tachygonetria and Alaeuris) were the main component of their helminthes infracommunities. The helminthes found as larval forms were located in the body cavity of the hosts, whereas those found as adults were located at different sites (Table 2).

\section{DISCUSSION}

Helminth faunas of lizards from both archipelagos were globally similar in including widespread helminth species, as the nematodes Skrjabinodon medinae and Parapharyngodon spp., the cestodes Nematotaenia tarentolae and Oochoristica spp., and several cestode and nematode larval forms.

Nevertheless, some differences are also found between both helminth faunas, namely regarding the endemisms. Pseudoparadistomum yaizaensis is an endemic genus and species parasitizing only Gallotia atlantica from Lanzarote Island (RoCA, 2003). This finding was interesting because (i) no dicrocoeliids had been found from other reptiles in Macaronesia; and (ii) another member of the same family was found in the Balearic Islands, Paradistomun mutabile which is distributed in the European Mediterranean Basin (RocA \& Hornero, 1994; RoCA, 1995). Since geographical separation of gene stocks is important in speciation phenomena, we could suggest an origin of P. yaizaensis from P. mutabile, considering that there may have been interchanges of helmin- 
Table 2: Presence/absence of the recorded helminth species in each host. P.l. Podarcis lilfordi; P.p. P. pityusensis; G.a. Gallotia atlantica; G.s. G. stehlini; G.g. G. galloti and G.c. G. caesaris.

\begin{tabular}{|c|c|c|c|c|c|c|c|}
\hline Helminth species & Site & P.1. & P.p. & G.a. & G.s. & G.g. & G.c. \\
\hline \multicolumn{8}{|l|}{ Digenea } \\
\hline Paradistomum mutabile & Gall bladder & $\bullet$ & - & & & & \\
\hline Pseudoparadistomum yaizaensis & Small intestine & & & $\bullet$ & & & \\
\hline Brachylaima sp. & Small intestine & $\bullet$ & $\bullet$ & & & & \\
\hline \multicolumn{8}{|l|}{ Cestoda } \\
\hline Oochoristica agamae & Small intestine & & & & - & & \\
\hline Oochoristica gallica & Small intestine & & $\bullet$ & & & & \\
\hline Nematotaenia tarentolae & Small intestine & & - & & - & & \\
\hline Diplopylidium acanthotetra (larvae) & Body cavity & & $\bullet$ & $\bullet$ & & & \\
\hline Dipylidium sp. (larvae) & Body cavity & & & $\bullet$ & & & \\
\hline Mesocestoides sp. (larvae) & Body cavity & & $\bullet$ & $\bullet$ & & & $\bullet$ \\
\hline \multicolumn{8}{|l|}{ Nematoda } \\
\hline Skrjabinodon medinae & Caecum & $\bullet$ & $\bullet$ & & & • & \\
\hline Spauligodon cabrerae & Caecum & $\bullet$ & $\bullet$ & & & & \\
\hline Spauligodon atlanticus & Caecum & & & - & - & - & $\bullet$ \\
\hline Spauligodon sp.* & Caecum & & & & & $\bullet$ & $\bullet$ \\
\hline Parapharyngodon micipsae & Caecum & $\bullet$ & $\bullet$ & $\bullet$ & $\bullet$ & $\bullet$ & $\bullet$ \\
\hline Parapharyngodon echinatus & Caecum & & $\bullet$ & $\bullet$ & - & & \\
\hline Parapharyngodon bulbosus & Caecum & $\bullet$ & - & & $\bullet$ & & \\
\hline Thelandros galloti & Caecum & & & & & $\bullet$ & $\bullet$ \\
\hline Thelandros filiformis & Caecum & & & & $\bullet$ & - & $\bullet$ \\
\hline Thelandros tinerfensis & Caecum & & & & & - & $\bullet$ \\
\hline Alaeuris numidica & Caecum & & & & $\bullet$ & $\bullet$ & $\bullet$ \\
\hline Tachygonetria dentata & Caecum & & & & $\bullet$ & & $\bullet$ \\
\hline Tachygonetria macrolaimus & Caecum & & & & - & & $\bullet$ \\
\hline Tachygonetria conica & Caecum & & & & $\bullet$ & & \\
\hline Tachygonetria numidica & Caecum & & & & $\bullet$ & & \\
\hline Skrjabinelazia hoffmanni & Small intestine & $\bullet$ & & $\bullet$ & - & & \\
\hline Skrjabinelazia pyrenaica & Stomach & & & & & & $\bullet$ \\
\hline Strongyloides ophiusensis & Small intestine & & $\bullet$ & & & & \\
\hline Abbreviata sp. & Small intestine & $\bullet$ & & & & & \\
\hline Acuaria sp. (larvae) & Body cavity & $\bullet$ & $\bullet$ & & & & \\
\hline Spirurida gen sp. (larvae) & Body cavity & $\bullet$ & - & & & & $\bullet$ \\
\hline \multicolumn{8}{|l|}{ Acanthocephala } \\
\hline Centrorhynchus sp. (larvae) & Body cavity & $\bullet$ & - & & & & $\bullet$ \\
\hline
\end{tabular}

*Unpublished data.

thes between both groups of lacertid lizards, Podarcis and Gallotia, as suggested by the composition of both helminth faunas. Other helminth species or subspecies endemic to the Canary Islands, as Spauligodon atlanticus, Spauligodon sp, Thelandros galloti, T. filiformis, T. tinerfensis and Alaeuris numidica canariensis were Gallotia specialists (sensu EDWARDS \& BusH, 1989) since they have been found in several Gallotia lizards and not in other hosts. Balearic lizards also harboured only two endemic helminth species, one of them, Strongyloides ophiusensis, being found in Podarcis pityusensis but not in P. lilfordi. One of 


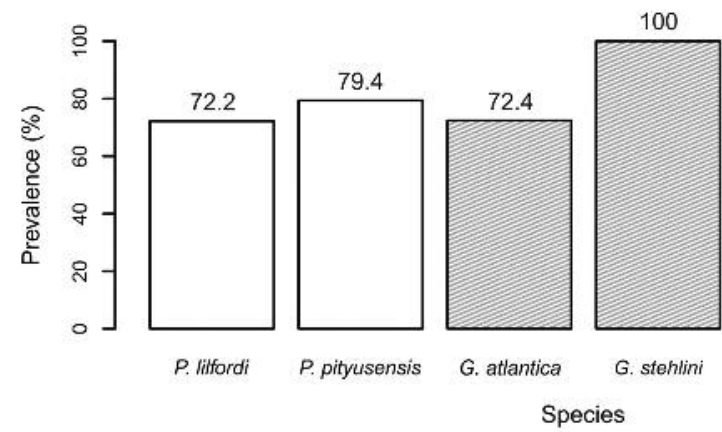

the most interesting differences among the endemisms is related to the Spauligodon species. In the Gallotia hosts, two different not related but resembling Spauligodon species are present, $S$. atlanticus parasite of $G$. atlantica and Spauligodon sp. found in the Gallotia species from the western islands (JORGE et al., 2011). Their colonization patterns are still unclear, and could have resulted from the host only colonizing the islands with a different subset of the two species, or extinctions or one of this species resulting from a host switch from another species. In the Podarcis present in the Balearic Islands, only one species has been found, S. cabrerae, probably resulting from colonization by descent.

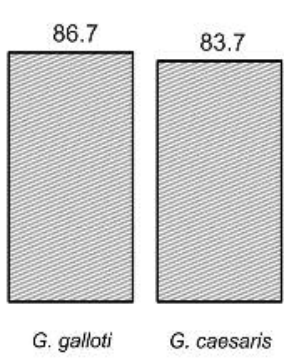

Figure 2: Overall prevalence of infection of the searched lizard hosts.

Family Pharyngodonidae is considered as good indicator of the diet of reptiles (RocA, 1999). In the different genera of this family parasitizing reptiles, two lines can be distinguished based mainly on the disposition of the genital papillae (PETTER, 1966). One of these lineages evolved in carnivorous reptiles (genera Pharyngodon, Spauligodon, Skrjabinodon and Parapharyngodon) and the other one in herbivorous reptiles (genera Alaeuris, Mehdiella, Tachygonetria and Thelandros) (PETTER \& QUENTIN, 1976; RocA, 1999). Both groups of Balearic and Canarian lizards harboured species belonging to the lineage of carnivorous reptiles, but

Table 3: Overall diversity parameters (mean $\pm \mathrm{SD}$, with the range in parentheses) from the searched hosts.

\begin{tabular}{lccc}
\hline \hline Host & No. of helminth species/host & No. of helminthes/host & Brillouin's diversity index \\
\hline Balearic Islands & & & \\
Podarcis lilfordi & $0.93 \pm 0.74$ & $7.45 \pm 12.84$ & $0.108 \pm 0.200$ \\
Podarcis pityusensis & $(0-4)$ & $(0-110)$ & $(0-0.815)$ \\
Canary Islands & $1.35 \pm 1.02$ & $16.44 \pm 31.22$ & $0.242 \pm 0.292$ \\
Gallotia atlantica & $(0-5)$ & $(0-420)$ & $(0-1.211)$ \\
& $1.0 \pm 0.8$ & $16.3 \pm 21.2$ & \\
Gallotia stehlini & $(0-4)$ & $(0-156)$ & $0.13 \pm 0.24$ \\
& $4.9 \pm 1.6$ & $468.2 \pm 644.6$ & $(0-0.89)$ \\
Gallotia galloti & $(2-7)$ & $(31-2734)$ & $(0.2 \pm 0.4$ \\
& $1.72 \pm 0.18$ & $54.4 \pm 14.28$ & $0.55 \pm 0.09$ \\
Gallotia caesaris & $(0-4)$ & $(0-373)$ & $(0-1.86)$ \\
& $1.4 \pm 1.0$ & $47.3 \pm 68.5$ & $0.3 \pm 0.4$ \\
& $(0-5)$ & $(0-350)$ & $(0-1.0)$ \\
\hline
\end{tabular}


only Canarian ones had eight helminth species typical of herbivorous reptiles. This suggested a strong tendency to herbivory of these hosts. Diversity of helminth communities has also been used to estimate the tendency of reptiles to eat plant matter. Herbivorous reptiles tend to contain richer and more diverse communities than carnivorous ones (RoCA, 1999). According to this, Gallotia stehlini and G. galloti from the Canary Islands showed major tendency to herbivory than other species from the archipelago, because their helminth communities were highly rich and diverse, so we may consider them as rich helminth communities (AHO, 1990). This was in accordance to the presence of Pharyngodonidae typical of herbivorous reptiles (MARTIN \& RocA, 2004a,b).

Diet analysis of gut contents (PÉREZMellado \& Corti, 1993; Brown \& PÉreZMEllado, 1994; RoCA, 1999; CARRETERO et al., 2001; VAlido \& NogALES, 2003; RocA et al., 2005; CARRETERO et al., 2006) allowed these Balearic and Canarian lizard species to be located in a continuum of the food type strategy, in extremes are strict carnivory and herbivory. Near of the end of herbivory we found G. stehlini, the "Giant lizard" from Gran Canaria Island which eats more than $94 \%$ of plan matter. Gallotia galloti from Tenerife and $G$. caesaris from El Hierro and La Gomera islands were omnivorous with marked tendency to herbivory (between 70\% and $85 \%$ of plant matter). Remarkably, Gallotia lizards consumed stems and leaves of the plants, which are of low profitability and require long fermentation periods for symbiotic flora to act (CARreTERO, 2004). By contrast, both Balearic lizards P. pityusensis and P. lilfordi (PÉREZ-MELlado \& CORTI,
1993; Carretero et al., 2001), and also the populations of $G$. atlantica from Lanzarote and Fuerteventura islands (authors' unpublished data), eat mainly arthropods and a little amount of plant matter, usually the most profitable parts such as fruits, seeds, flowers or pollen, and so we found them near of the end of carnivory.

Results from the analysis of helminthes (MARTIN \& RoCA, 2004a,b; MARTIN \& RocA, 2005; RocA et al., 2005) placed these lizard species in the same carnivory-herbivory continuum, according to their helminth community features mentioned above. We found a full coincidence of the position of $G$. stehlini in the continuum, due to its helminthological characteristics (high diversity, presence of many Pharyngodonidae of the lineage of herbivorous reptiles). It is the biggest and the most herbivorous lizard, with the most diverse helminth community. High coincidence was also found in the case of $G$. galloti showing relatively high diversity and presence of some peculiar species of Pharyngodonidae, as happens with $G$. caesaris. Low diversity and absence of pharyngodonids typical of herbivorous reptiles placed $G$. atlantica and both Podarcis at the end of the carnivory, in accordance with the results of their feeding habits. The tendency to a restricted herbivory (consumption of the most energetic parts of plants) observed in Balearic lizards (PÉREZMELLADO \& CORTI, 1993) is not reflected in their helminth communities. Thus, RocA (1999) suggested that they are primarily carnivorous reptiles and we suggest the same for $G$. atlantica. It has been proposed that such differences between both lizard genera are related to the different times of evolution under insular conditions (CARRETERO, 
2004). In particular, the absence or the impoverishment of terrestrial predatory species releasing lizards for devoting more time for eating (PÉREZ-MELlado \& CORTI, 1993) together with prolonged lizard basking at high temperatures (MÁRQUEZ et al., 1997) and the retention of prey items in a compartmented rectal caecum (HERREL et al., 2004) would not only enhance prey digestion (ZimMERMAN \& TRACY, 1989), but also provide a favourable ambient for distinctive, more complex helminth communities.

In accordance with the reasons mentioned above, we can conclude the following: (i) the composition and structure of helminth communities of these reptile hosts are related to their phylogeny and their feeding habits; (ii) the tendency to the herbivory is much more marked in Canary lacertid lizards than in Balearic ones.

\section{Acknowledgement}

Permits for collecting living specimens were granted by the Viceconsejería de Medio Ambiente of the Canarian Government, and the Conselleria de Agricultura i Pesca of the Balearic Islands Government. The authors carried out the work in accordance with the relevant regulations concerning the capture and handling of animals.

\section{REFERENCES}

Arnold, E.N.; Arribas, O.J. \& CarranZa, S. (2007). Systematics of the Palaearctic and Oriental lizard tribe Lacertini (Squamata: Lacertidae: Lacertinae), with descriptions of eight new genera. Zootaxa 1430: 1-8.

Brown, R.P. \& PÉREZ-MELlado, V. (1994). Ecological energetics and food acquisition in dense Menorcan islet populations of the lizard Podarcis lilfordi. Functional Ecology 8: 427-434. Bush, A.O.; Laferty, K.D.; LOFT, J.M. \& SHostak, A.W. (1997). Parasitology meets ecology on its own terms: Margolis et al. revisited. Journal of Parasitology 83: 575-583.

Carretero, M.A. (2004). From set menu to a la carte. Linking issues in trophic ecology of Mediterranean lacertids. Italian Journal of Zoology 74: 121-133.

Carretero, M.A. (2006). Reproductive cycles in Mediterranean lacertids: plasticity and constraints, In C. Corti, P. Lo Cascio \& M. Biaggini (eds.) Mainland and Insular Lizards. A Mediterranean Perspective. Firenze University Press, Florence, Italy, pp. 33-54.

Carretero, M.A.; Llorente, G.A.; Santos, X. \& MONTORI, A. (2001). The diet of an introduced population of Podarcis pityusensis. Is herbivory fixed?, In L. Vicente \& E.G. Crespo (eds.) Mediterranean Basin Lacertid Lizards. A Biological Approach. ICN, Lisbon, Portugal, pp. 113-124.

Carretero, M.A.; Roca, V.; Martin, J.E.; Llorente, G.A.; Montori, A.; Santos, X. \& Mateos, J. (2006). Diet and helminth parasites in the Gran Canaria giant lizard Gallotia stehlini. Revista Española de Herpetología 20: 105-117.

Cavazza, W. \& Wezel, F.C. (2003). The Mediterranean region, a geological primer. Episodes 26: 160-168.

Cox, S.C.; Carranza, S. \& Brown, R.P. (2010). Divergence times and colonization of the Canary Islands by Gallotia lizards. Molecular Phylogenetics and Evolution 56: 747-757.

Edwards, D.D. \& Bush, A.O. (1989). Helminth communities in avocets: 
importance of compound community. Journal of Parasitology 98: 439-445.

Goüy de Belloce, J.; Morand, S. \& Feliu, C. (2002). Patterns of parasite species richness of Western Palaearctic micromammals: island effects. Ecography 25: 173-183.

Harris, D.J.; ARnold, E.N. \& Thomas, R.H. (1998). Relationships of lacertid lizards (Reptilia: Lacertidae) estimated from mitochondrial DNA sequences and morphology. Proceedings of the Royal Society of London B 265: 1939-1948.

Herrel, A.; VanhoOydonck, B. \& VAN DAMME, R. (2004). Omnivory in lacertid lizards: adaptive evolution or constrait?. Journal of Evolutionary Biology 17: 974-984. Jorge, F.; Roca, V.; Perera, A.; Harris, D.J. \& CARretero, M.A. (2011). A phylogenetic assessment of the colonisation patterns in Spauligodon atlanticus Astasio-Arbiza et al., 1987 (Nematoda: Oxyurida: Pharyngodonidae), a parasite of lizards of the genus Gallotia Boulenger: no simple answers. Systematic Parasitology 80: 53-66.

Jorge, F.; Carretero, M.A.; Perera, A.; HarRis, D.J. \& RocA, V. (2012). A new species of Spauligodon (Nematoda: Oxyurida: Pharyngodonidae) in geckos from Sao Nicolau island (Cape Verde) and its phylogenetic assessment. Journal of Parasitology 98: 160-166.

MACA-MEYER, N.; CARRANZA, S.; RANDO, J.C.; ARNold, E.N. \& CABRERA, V.N. (2003). Status and relationships of the extinct giant Canary Island lizard Gallotia goliath (Reptilia: Lacertidae), assessed using ancient mtDNA from its mummified remains. Biological Journal of the Linnean Society 80: 659-670.

Magurran, A.E. (2004). Measuring Biological Diversity. Blackwell Publishing,
Malden, Massachusetts, USA.

Márquez, R.; Cejudo, D. \& PéreZ-Mellado, V. (1997). Selected body temperatures of four lacertid lizards from the Canary Islands. Herpetological Journal 7: 122-124.

MarTin, J.E. \& RoCA, V. (2004a). Helminth infracommunities of Gallotia caesaris caesaris and Gallotia caesaris gomerae (Sauria: Lacertidae) from the Canary Islands (Eastern Atlantic). Journal of Parasitology 90: 266-270. Martin, J.E. \& RoCA, V. (2004b). Helminth infracommunities of a population of the Gran Canaria giant lizard Gallotia stehlini. Journal of Helminthology 78: 319-322.

Martin, J.E. \& RoCA, V. (2005). Helminths of the Atlantic lizard Gallotia atlantica (Reptilia, Lacertidae), in the Canary Islands (Eastern Atlantic): Composition and structure of component communities. Acta Parasitologica 50: 85-89.

MAs-Coma, S.; Esteban, J.G.; Fuentes, M.V.; Bargues, M.D.; VAlero, M.A. \& GaláNPuCHADES, M.T. (2000). Helminth parasites of small mammals (insectivores and rodents) on the Pityusic island of Eivissa (Balearic Archipelago). Research and Reviews in Parasitology 60: 41-49.

MeIRI, S. (2007). Size evolution in island lizards. Global Ecology and Biogeography 16: 702-708.

Nieberding, C.; Morand, S.; Libois, R. \& MichauX, J.R. (2006). Parasites and the island syndrome: the colonization of the western Mediterranean islands by Heligmosomoides polygyrus (Dujardin, 1845). Journal of Biogeography 33: 1212-1222.

Novosolov, M.; Raia, P. \& Meiri, S. (in press). The island syndrome in lizards. Global Ecology and Biogeography DOI: 10.1111/j.1466-8238.2012.00791.x. 
Pavlicev, M. \& Mayer, W. (2009). Fast radiation of the subfamily Lacertinae (Reptilia: Lacertidae): History or methodical artefact? Molecular Phylogenetics and Evolution 52: 727-734.

Pérez-Mellado, V. \& Corti, C. (1993). Dietary adaptations and herbivory in lacertid lizards of the genus Podarcis from western Mediterranean islands (Reptilia: Sauria). Bonner Zoologische Beiträge 44: 193-220.

PetTer, A.J. (1966). Équilibre des espèces dans les populations de nématodes parasites $\mathrm{du}$ colon des tortues terrestres. Mémoires du Muséum Nationale d'Histoire Naturelle Série A Zoologie 39: 1-252.

PetTer, A.J. \& Quentin, J.C. (1976). Keys to Genera of the Oxyuroidea. Series: C.I.H. Keys to the Nematode Parasites of Vertebrates, vol. 4 (R.C. Anderson, A.G. Chabaud \& S. Willmott, eds.). CAB International, Farhan Royal, London, UK. RocA, V. (1993). Helmintofauna dels rèptils, In J.A. Alcover, E. Ballesteros \& J.J. Fornós (eds.) Història Natural de l'Arxipelag de Cabrera. CSIC-Editorial Moll, Palma de Mallorca, Spain, pp. 273-292.

RocA, V. (1995). An approach to the knowledge of the helminth infracommunities of Mediterranean insular lizards (Podarcis spp.), In G.A. LLorente, A. Montori, X. Santos \& M.A. Carretero (eds.) Scientia Herpetologica. Asociación Herpetológica Española, Barcelona, Spain, pp. 285-292. RoCA, V. (1999). Relación entre las faunas parásitas de reptiles y su tipo de alimentación. Revista Española de Herpetología 13: 101-121. RocA, V. (2003). A new genus of Dicrocoeliidae (Digenea) from the lizard Gallotia atlantica (Sauria: Lacertidae) from the Canary Islands (Spain). Journal of Natural History 37: 1401-1406.

Roca, V. \& Hornero, M.J. (1994). Helminth infracommunities of Podarcis pityusensis and Podarcis liffordi (Sauria: Lacertidae) from the Balearic Islands (western Mediterranean Basin). Canadian Journal of Zoology 72: 658-664.

Roca, V.; García-Adell, G.; López, E. \& ZapaTero-Ramos, L.M. (1987). Algunas formas adultas y larvarias de platelmintos de reptiles de las islas Canarias. Revista Ibérica de Parasitología 47: 263-270.

RoCA, V.; CARRETERO, M.A.; LLORENTE, G.A.; Montori, A. \& Martin, J.E. (2005). Helminth communities of two lizard populations (Lacertidae) from Canary Islands (Spain): Host-diet parasite relationships. Amphibia-Reptilia 26: 535-542.

Roca, V.; Lo Cascio, P. \& Martin, J.E. (2006). Gastrointestinal parasites in saurians from some central Mediterranean islands. Boletín de la Asociación Herpetológica Española 17: 54-58.

Roca, V.; Foufopoulos, J.; Valakos, E. \& PAfILIS, P. (2009). Parasitic infracommunities of the Aegean wall lizard Podarcis erhardii (Lacertidae, Sauria): isolation and impoverishment in small island populations. Amphibia-Reptilia 30: 493-503.

Valido, A. \& Nogales, M. (2003). Digestive ecology of two omnivorous Canarian lizard species (Gallotia, Lacertidae). AmphibiaReptilia 24: 331-344.

VAN DAMME, R. (1999). Evolution of herbivory in lacertid lizards: effects of insularity and body size. Journal of Herpetology 33: 663-674. ZimMerman, L.C. \& TraCY, C.R. (1989). Interactions between the environment and ectothermy and herbivory in reptiles. Physiological Zoology 62: 374-409. 